\title{
KEPRIBADIAN TOKOH SENIMAN DAN GADIS MUDA DALAM CERPEN WAJH AL-HAQIQĀH
}

\author{
Nur Intan Fatmawati \\ Universitas Sebelas Maret \\ Email: intannur507@gmail.com \\ Ervina Pradestya Indriyani \\ Email: ervina.indri212@gmail.com \\ Eva Farhah \\ Universitas Sebelas Maret \\ Email: evafarhah@staff.uns.ac.id
}

\begin{abstract}
This article aims at describing the personalities of characters in Wajh Al-Haqiqāh shortstory by Taufíq Al-Chakim based on Carl GustavJung's theory of personality. Data used in this research were obtained from primary and secondary data. Primary data source in this research is Wajh Al-Haqiqāh shortstory by Taufiq Al-Chakim and secondary data sources are books, journals, and internet sources relevant to this study. The problem analyzed in this research is the personality of each character in Wajh Al-Haqiqāh shortstory by Taufĩ Al-Chakìm. When explaining the research problem, the researchers applied Cal Gustav Jung's theory of personality. The results of analysis show that each character has different personalities. The structure of human's soul consists of two worlds, consciousness and unconsciousness.
\end{abstract}

Keywords: Wajh Al-Haqiqāh, psichology, Carl Gustav Jung, shortstory.

\begin{abstract}
ABSTRAK
Artikel ini bertujuan untuk mendeskripsikan kepribadian tokoh-tokoh dalam cerpen Wajh Al-Haqiqāh karya Taufīq Al-Chakīm berdasarkan teori psikologi kepribadian Carl Gustav Jung melalui perspektif strukturalisme. Metode penelitiannya adalah metode kulaitatif. Masalah penelitian berupa kepribadian tokoh dalam cerpen Wajh Al-Haqiqāh karya Taufīq Al-Chakīm. Hasil analisis menunjukkan bahwa setiap tokoh memiliki kepribadian yang berbeda-beda. Struktur jiwa manusia terdiri dari dua alam, yaitu alam sadar
\end{abstract}


dan alam tidak sadar. Hal itu ditunjukkan melalui dua tokoh yang berperan dalam cerita pendek ini. Kedua tokoh itu adalah tokoh Seniman dan tokoh Wanita

Kata kunci: Wajh Al-Haqiqāh, psikologi, Carl Gustav Jung, cerpen.

\section{PENDAHULUAN}

Sehadi (2014: 1) mendefinisikan pengertian sastra menjadi dua. Pengertian pertama, sastra adalah hasil karya seni para pengarang atau sastrawan, yang antara lain berupa prosa, puisi, dan drama. Pengertian pertama ini disebut karya sastra atau sastra kreatif. Kedua, sastra adalah ilmu pengetahuan atau bidang ilmu yang mempelajari karya-karya sastra (prosa, puisi, dan drama), yang dikenal dengan nama ilmu sastra atau sastra ilmiah. Sejalan dengan pemikiran tersebut, Wellek dan Warren (1990, h.25) menjelaskan bahwa secara garis besar karya sastra terbagi menjadi tiga kategori, yaitu puisi, prosa, dan drama.

Dari ketiga kategori karya sastra tersebut, artikel ini membahas prosa. Teeuw (1984, h.15) mengungkapkan, prosa adalah bentuk karya sastra fiksi yang mengangkat suatu kenyataan. Salah satu bentuk prosa adalah cerpen atau cerita pendek. Cerpen adalah rangkaian peristiwa yang terjalin menjadi satu yang didalamnya terjadi konflik antartokoh atau dalam diri tokoh itu sendiri dalam latar dan alur (Kurniawan, Heru, dan Sutardi, 2012, h.59). Yohanes (dalam Suharianto, 1982, h.39) juga menjelaskan bahwa cerpen adalah sebuah cerita prosa yang pendek yang senantiasa hanya memusatkan perhatian pada tokoh utama dan permasalahannya yang paling menonjol yang menjadi dasar atau tema cerita tersebut. Salah satu antologi cerpen
Arinillāh adalah Wajh Al-Haqiqāh karya Taufīq Al-Chakìm yang diteliti dalam artikel ini.

Penelitianinibertujuanbertujuan untuk mendeskripsikan kepribadian tokoh-tokoh dalam cerpen Wajh AlHaqiqāh karya Taufīq Al-Chakīm. Hal itu dilakukan dengan mendasarkan pada teori psikologi kepribadian Carl Gustav Jung. Berdasarkan hasil penelusuran yang dilakukan, cerpen Arinillāh karya Taufīq Al-Chakīm ini telah dikaji oleh sejumlah peneliti terdahulu. Hal tersebut terbukti dari hasil temuan penlitian yang berbentuk skripsi.

Pertama adalah penelitian yang menggunakan teori psikologi sastra sebagai alat untuk menganalis. Penelitian itu dilakukan oleh Nurul Khoidah (2017) dalam "Kepribadian Tokoh Protagonis dan Antagonis dalam Ast'ab Fi Biladil Waq Waq (2002) dan Asy'ab I Mchnah (2002) Kajian Psikologi Sasra". Penelitian tersebut membahas tentang kondisi dan perkembangan jiwa seseorang yang tidak lepas dari faktor internal yang berasal dari diri pribadinya itu sendiri. Faktor internal tersebut di tentukan oleh kekuatan energi psikis yang ditimbulkan dari tiga aspek kepribadan, yaitu id, ego dan superego.

Kedua adalah penelitian yang dilihat dari segi kepengarangannya. Penelitian itu dilakukan oleh Kumala (2014) dalam "Al-Qishoh Al-Qoshiroh Imroah Gholabat Syaitan Li Taufíq AlChakìm (Dirasah Tahliyan Sikulujiya 
Lil Victor Franki)". Penelitian tersebut membahas tentang unsur-unsur psikologis yang ada di dalam cerpen tersebut. Tujuan dari penelitian itu adalah untuk megetahui konflik yang dialami oleh tokoh utama dalam cerpen tersebut.

Ketiga adalah penelitian oleh Farkhati (2014), yang "Aspek Kepribadian \& Profil Tokoh Utama dalam Kumpulan Cerpen Arinillāh Karya Taufíq A-Chakim (Analisis Psikologi Sastra Sigmund Freud)". Penelitian ini membahas struktur cerita yang meliputi tema, penokohan, plot, latar atau setting, amanat dan aspek kepribadian tokoh utama yang terdapat dalam kumpulan cerpen Arinillāh dengan menggunakan teori psikologi Sigmund Freud. Berdasarkan hasil penelitian tersebut, penelitian ini mengambil sebuah asumsi bahwa karya yang berjudul Wajh Al-Haqiqāh dari Taufĩq Al-Chakīm menunjukkan karakteristik psikologis bila dibandingkan dengan cerita atau karya yang lainnya.

\section{TEORI DAN METODE PENELITIAN}

\section{Menurut Alwisol (2009,}

h.2), teori psikologi kepribadian itu mempelajari individu secara spesifik, seperti siapa dia, apa yang dimilikinya dan yang dikerjakannya. Oleh karena itu, Alwisol mendeskripsikan kepribadian merupakan bagian dari jiwa yang membangun keberadaan manusia menjadi satu kesatuan yang tidak terpecah belah dalam fungsifungsi (Alwisol, 2014, h.2). Memahami kepribadian berarti memahami aku, diri atau self, atau memahami manusia seutuhnya.

Menurut Jung, kepribadian atau psyche adalah totalitas mengenai segala peristiwa psikis baik yang disadari mau pun yang tidak disadari (Suryabrata, 2007, h.156). Dengan demikian, struktur jiwa manusia terdiri dari dua alam, yaitu alam sadar (kesadaran) dan alam tidak sadar (ketidaksadaran). Kedua struktur jiwa tersebut tidak hanya saling mengisi. Akan tetapi, keduanya berhubungan secara kompensatoris (Suryabrata, 2007, h.157). Adapun fungsi keduanya adalah penyesuaian, yaitu alam sadar yang merupakan penyesuaian terhadap dunia luar dan alam tak sadar yang merupakan penyesuaian terhadap dunia dalam.

Batas antara kedua alam tersebut tidak tetap, melainkan dapat berubah-ubah. Artinya, luas daerah kesadaran dan ketidaksadaran itu dapat bertambah atau berkurang. Kedua struktur jiwa tesebut diuraikan sebagai berikut. Pertama, struktur kesadaran mempunyai dua komponen pokok, yaitu fungsi jiwa dan sikap jiwa. Keduanya mempunyai peranan penting dalam orientasi manusia di dalam dunianya (Suryabrata, 2007, h.158). Fungsi jiwa adalah suatu bentuk aktivitas kejiwaan yang secara teori tidak berubah di dalam lingkungan yang berbeda. Fungsi jiwa terdiri dari empat fungsi pokok, yaitu pikiran, perasaan, pengindraan, dan intuisi. Jung membedakan empat fungsi pokok tersebut menjadi dua rasional yang meliputi pikiran dan perasaan, serta dua irrasional yang meliputi pengindraan dan intuisi.

Pertama, pikiran adalah fungsi intelektual. Dia juga mencari hubungan antar ide untuk memahami alam dunia dan memecahkan masalah. Kedua, perasaan adalah fungsi evaluasi, menerima atau menolak sebuah ide dengan mempertimbangkan perasaan positif atau negative. Dia memberi pengalaman subjektif manusia, seperti 
kenikmatan, rasa sakit, takut, marah, sedih, gembira, dan cinta. Oleh karena itu, pikiran dan perasaan adalah fungsi rasional karena keduanya melibatkan suatu keharusan untuk memutuskan sesuatu, yakni apakah dua ide tersebut saling berhubungan atau tidak (berfikir) dan menyenangkan atau tidak (perasaan). Ketiga, penginderaan adalah fungsi perseptual atau kenyataan, menghasilkan fakta-fakta konkret. Penginderaan melibatkan operasi dari indera penglihatan, pendengaran, peraba, perasa, pembau, dan rangsangan dari dalam tubuh sendiri. Keempat, intuisi adalah persepsi secara tak sadar, memperoleh suatu kebenaran tanpa melalui fakta. Penginderaan dan intuisi adalah fungsi irrasional, karena keduanya merespon stimulus, baik nyata maupun tidak dan tidak melalui pikiran (Jung dalam Alwisol, 2009. h.46).

Kedua, sikap jiwa adalah arah energi psikis umum dalam bentuk orientasi manusia teradap dunianya. Arah energi psikis tersebut sebanding dengan arah orientasi manusia terhadap dunia, yaitu ke luar atau ke dalam (Suryabrata, 2007, h.161).

Jung (dalam Alwisol, 2009, h.4546) membagi sikap jiwa menjadi dua, yaitu introvers dan ekstravers. Sikap introvers mengarahkan kepribadian kepada pengalaman subjektif. Dia memusatkan diri kepada dunia dalam dan cenderung bersifat privasi, suka menyendiri, dan pendiam. Pada umumnya, orang yang bersikap introvers sibuk dengan kehidupan internal mereka sendiri. Sikap ekstravers mengarahkan kepribadian kepada pengalaman objektif, dengan memusatkan perhatiannya ke dunia luar, suka berinteraksi dengan orang- orang yang berada di sekitarnya, peduli, aktif dan ramah. Orang yang mempunyai sikap ekstravers sangat menaruh perhatian terhadap dunia luar dan dunia di sekitarnya, aktif, santai, dan tertarik kepada dunia luar.

Kedua sikap tersebut merupakan sikap yang berlawanan. Akan tetapi, ada salah satu yang dominan dan sadar, sedangkan yanglainnya kurang dominan dan taksadar. Apabila Ego lebih bersifat ekstraver dalam berhubungan dengan dunia luar, taksadar pribadinya bersifat introvert. Begitu pula sebaliknya, apabila ego lebih bersifat introvert, taksadar pribadinya bersifat ekstravert. Struktur ketidaksadaran terdiri dari dua komponen, yaitu ketidaksadaran pribadi dan ketidaksadaran kolektif (Suryabrata, 2007, h.165-166).

Pertama adalah ketidaksadaran pribadi. Ketidaksadaran pribadi berisi hal-hal yang diperoleh dari individu selama hidupnya (Suryabrata, 2007, h.165). Kedua adalah ketidaksadaran kolektif. Hal itu mengandung isi-isi yang diperoleh selama pertumbuhan jiwa seluruhnya, yaitu pertumbuhan jiwa seluruh jenis manusia, melalui generasi yang terdahulu (Suryabrata, 2007, h.166). Sejalan dengan pengertian diatas, Alwisol menjelaskan kesadaran kolektif adalah gudang ingatan yang diwariskan oleh leluhur, baik leluhur yang berwujud manusia atau leluhur pramanusia. Ingatan yang diwariskan tersebut adalah pengalamanpengalaman umum yang terus menerus diulang-ulang dari satu generasi ke generasi lainnya (Alwisol, 2009, h.41).

Akan tetapi, penelitian ini hanya menguraikan struktur kesadaran dalam dua tokoh saja, yaitu tokoh utama dan tokoh bawahan. Struktur kesadaran terdiri dari fungsi jiwa dan sikap jiwa. 
Fungsi jiwa meliputi pikiran, perasaan, penginderaan dan intuisi. Sikap jiwa terdiri atas introvers dan ekstravers.

Metode yang digunakan dalam penelitian ini adalah metode kualitatif deskriptif. Penelitian kualitatif adalah penelitian yang bertujuan untuk melihat fenomena yang dialami oleh subjek penelitian seperti, perilaku, tindakan, motivasi dan lain sebagainya. Hal itu dilakukan dengan menggunakan cara deskriptif dalam bentuk kata-kata dan bahasa (Moleong, 2010, h.6).

Objek dalam penelitian ini adalah teks sastra yang berjudul Wajh AlHaqiqah sebagai objek material. Objek formalnya adalah kepribadian tokoh cerita. Data yang digunakan adalah dialog-dialog dalam teks sastra tersebut, isi cerita, dan simbol-simbol cerita yang berhubungan dengan kepribadian sang tokoh. Teknik pengumpulan data dilakukan dengan cara teknik simak dan catat.

\section{HASIL DAN PEMBAHASAN}

Tata Naratif Cerita Pendek Wajh AlHaqiqāh

Tata naratif dalam teks ini difokuskan pada rangkaian-rangkaian peristiwa yang membentuk kesatuan cerita. Dalam terminologi kajian struktural, hal ini dinamakan alur cerita. Hal ini diuraiakan sebagai bagian dari upaya memperjelas posisi cerita, tindakan tokoh cerita, dan juga lataryang terlibat di dalamnnya. Melalui tindakan dan motivasi tersebut, karakteristik tokoh cerita secara struktural dapat diketahui.

Cerpen Wajh Al-Haqiqāh
menceritakan tentang kehidupan
seorang seniman yang selalu
berpindah-pindah tempat tinggal,
dari losmen satu ke losmen yang lain.

Seniman tersebut selalu menuliskan cerita kehidupannya dan kemudian diterbitkan oleh sahabatnya yang bekerja sebagai penerbit. Hingga suatu ketika, seniman tersebut menyadari bahwa selama sepuluh tahun dia tidak pernah merasakan jatuh cinta.

Pada suatu ketika, seniman tersebut melihat seorang gadis cantik yang bertempat tinggal di samping kamar losmen yang dia tempati saat itu. Seniman tersebut merasakan ada rasa aneh dan berbeda terhadap gadis muda tersebut. Ternyata, seniman tersebut telah jatuh cinta kepada gadis muda itu.

Satu hal membuat seniman tersebut kaget, yakni ternyata si gadis sudah terikat tali pernikahan dengan seorang pemuda tampan selama dua tahun. Akan tetapi, setelah mengetahui cerita yang sebenarnya tentang gadis tersebut, seniman itu semakin ingin dekat dengan si gadis. Oleh karena itu, seniman tersebut merasa iba terhadap berbagai permasalahan yang di alami oleh si gadis. Sebagai akibtanya, dia ingin membantu si gadis supaya melakukan hal-hal yang berguna dan menjadi seorang gadis yang mempunyai nilai lebih.

Seniman mencoba menuliskan surat yang berisikan tentang nasihat untuk si gadis. Hal itu merupakan salah satu cara yang bisa dilakukan seniman untuk membantu si gadis meringankan masalah yang sedang dihadapi. Akan tetapi, setelah membaca suratitu, si gadis merasa tersinggung dan menunjukkan sikap dingin terhadap seniman. Hal itu membuat seniman semakin frustasi. Suatu hari, seniman memutuskan untuk meninggalkan losmen tersebut dan berpindah ke losmen lain supaya jauh dari gadis itu. 
Hari demi hari dia lalui. Suasana losmen baru yang dia tempati tersebut sangat tenang. Hal itu disebabkan bahwa di dalam losmen itu hanya terdapat dua kamar, yaitu satu kamar seniman dan satu lagi ditempati oleh seorang kakek tua, berjenggot dan sakit batuk. Akhirnya, pada hari berikutnya, datanglah seorang sahabat dan menyampaikan berita yang sangat mengejutkan. Kabar itu adalah bahwa sesuatu yang selama ini diketahui oleh seniman tentang si gadis muda tersebut hanyalah sebuah kebohongan. Sesuatu yang diketahui oleh sang seniman itu hanya rekaya dari si gadis. Si gadis sebenaranya hanya hidup sendiri sebatang karang. Dia tidak memiliki keluarga. Seorang pemuda yang dianggap sebagai suaminya itu ternyata hanyalah mucikarinya.

Seniman tersebut sangat kaget. Dia tidak percaya. Dia juga tidak dapat berkomentar apapun. Suaranya seperti terjengkal. Akan tetapi, dia berusaha untuk untuk tenang dan tidak marah. Sayangnya, seniman tersebut tidak dapat menahan kemarahan dan kekecewannya. Akhirnya, dia berteriak kepada sahabatnya "Kenapa kau datang hanya untuk menceritakan semuanya kepadaku?".

\section{Kepribadian Tokoh Seniman dalam Cerita Pendek Wajh Al-Haqiqāh}

Tokoh-tokoh dalam cerpen Wajh Al-Haqiqāh terdiri dari delapan tokoh yaitu Seniman, Penerbit, Gadis Muda, Suami Gadis Muda, Ibu dari Suami Gadis Muda, Rekan Kerja dari Suami Gadis Muda, Ibu pemilik losmen dan Kakek Tua. Tokoh utama dalam cerpen Wajh Al-Haqiqāh adalah seorang seniman. Pada setiap bagian dari cerita maupun peristiwa, tokoh Seniman mendominasi kehadiran dan pergerakan tata naratif cerita. Setiap tingkah lakunya mengerakkan jalannya sebuah cerita. Selain itu, pendeskripsian tokoh utama juga lebih dominan bila hal itu dibandingkan tokoh-tokoh yang lain.

Sebagaimana telah dijelaskan, kesadaran mempunyai dua komponen pokok, yaitu fungsi jiwa dan sikap jiwa. Jung (dalam Suryabrata, 2007, h.158) menjelaskan fungsi jiwa adalah suatu bentuk aktivitas kejiwaan yang secara teori tidak berubah di dalam lingkungan yang berbeda. Fungsi jiwa terdiri dari empat fungsi pokok, yaitu pikiran, perasaan, penginderaan dan intuisi. Jung membedakan empat fungsi pokok tersebut menjadi dua rasional yang meliputi pikiran dan perasaan, serta dua irasional yang meliputi penginderaan dan intuisi.

Kepribadian tokoh Seniman terbentuk secara sadar. Kepribadian tersebut terbentuk karena lingkungan sekitarnya. Lingkungan sangat berpengaruh besar terhadap kepribadian seseorang. Salah satu lingkungan yang mempengaruhi kepribadian Seniman adalah lingkungan tempat tinggalnya. Seniman tersebut merupakan seorang laki-laki yang selalu berpindah-pindah tempat tinggal dari satu losmen ke losmen yang lain. Dia selalu menyembunyikan tempat tinggalnya dari semua orang. Bahkan, dia juga menyembunyikan tempat tinggalnya dari sahabatnya sendiri. Saat ini, Seniman bertempat tinggal di sebuah losmen.

Di setiap harinya, dia selalu menuliskan semua kegiatan dan perjalanan hidupnya ke dalam lembaran kertas dengan menggunakan tinta kemudian diterbitkan oleh sahabatnya. Sampai pada akhirnya, dia merasakan 
bosan dengan aktivitasnya tersebut. Hal tersebut dapat diketahui dari ucapannya sebagai berikut.

$$
\begin{aligned}
& \text { لا ... لن أكتب شيئا ... لقد سئمت هذه الحياة } \\
& \text {... أريد مرة واحدة أن أحب للحب ... (الحكيم، INV }
\end{aligned}
$$$$
(1999
$$

\section{Artinya:}

Tidak. Aku tidak akan menulis apapun. Aku telah bosan dengan kehidupan ini. Aku ingin merasakan cinta. Sekalipun, semuanya itu harus kurasakan satu kali saja (AlChakīm, 1999, h.187).

Kutipan tersebut menunjuk-kan bahwa Seniman telah merasa bosan dengan kehidupannya saat ini. Dia tidak ingin lagi menulis. Rasa bosan itu timbul secara sadar dari perasaan seniman. Bosan merupakan perasaan tidak senang, atau perasaan yang membuatnya tidak nyaman. Seperti yang telah dijelaskan Jung (dalam Alwisol, 2009, h.46) bahwa perasaan adalah fungsi evaluasi, menerima atau menolak sebuah ide dengan mempertimbangkan perasaan positif atau negatif, memberi pengalaman subjektif manusia, seperti kenikmatan, rasa sakit, takut, marah, sedih, gembira dan cinta.

Selain itu, kepribadian tokoh seniman berdasarkan fungsi jiwa merupakan orang yang bertipe perasa. Cara kerja tipe perasa ini dinyatakan dengan memberikan penilaian terhadap sesuatu. Hal itu juga didasarkan pada kriteria menyenangkan atau tidak menyenangkan. Pada suatu waktu, Seniman tersebut merasakan ada sesuatu yang berbeda. Sikap dan perilakunya menjadi aneh. Kini, dia menjadi seorang yang terus mengawasi kehidupan seorang gadis muda yang bertempat tinggal di losmen yang sama dengannya, lebih tepatnya dikamar sebelahnya. Ternyata, dia telah jatuh cinta kepada gadis muda tersebut. Dia menyadari bahwa ada yang sedang dia rasakan saat ini. Sekarang ini, dia tidak lagi merasakan bosan. Bahkan, dia merasakan bahwa hari-harinya dipenuhi dengan berbagai peristiwa sehingga kehidupannya lebih berwarna dan menarik. Hal itu diungkapkan sebagai berikut.

$$
\begin{aligned}
& \text { إنى أنظر الآن و هي تجرى فيه حياقا فلا أسأم، بل } \\
& \text { النهر الضيق الصغير الذى بترى فيه حياتا فلا أسأم، بل إنى } \\
& \text { لأرى أيامى الآن عريضة عميقة زاخرة بأحداث و تفاصيل و } \\
& \text { مشاعر و مناظر (الحكيم, •1999: }
\end{aligned}
$$

Artinya:

Sekarang ini, aku tengah melihat kehidupanku yang terus berjalan di ruangan sempit dan kecil ini. Di mana, di tempat yang sama, gadis tersebut juga menjalani kehidupannya. Oleh karena itu, aku tidak merasa bosan. Bahkan, sekarang ini, aku melihat harihariku dipenuhi oleh berbagai peristiwa, berbagai warna kehidupan, perasaan indah dan berbagai pemandangan menarik (Al-Chakīm, 1999, h.190).

Kutipan tersebut menerangkan bahwa Seniman melakukan pekerjaan berdasarkan penilaian yang menyenangkan dan tidak menyenangkan. Hal itu seperti yang dilakukan oleh tokoh Seniman ketika dia merasakan kehidupannya telah 
berubah. Perubahan itu terlihat dari yang awalnya dia merasa bosan, kini dia merasakan kehidupan yang lebih berwarna. Hari-hari tokoh Seniman dipenuhi dengan berbagai peristiwaperistiwa sehingga hari-harinya lebih menarik. Semua itu disebabkan oleh kehadiran gadis muda tersebut ke dalam dunianya. Peristiwa tersebut merupakan sebuah perasaan seniman yang menyenangkan. Seperti yang telah dijelaskan oleh Jung (dalam Alwisol, 2009, h.46) bahwa salah satu perasaan adalah cinta. Cinta mampu memberikan pengalaman subjektif bagi manusia. Kini, dia telah menemukan kehidupan yang lebih baik sehingga membuat hariharinya lebih berwarna dan menarik.

Akan tetapi, setelah tokoh Seniman mengetahui bahwa si gadis muda tersebut telah terikat tali pernikahan dengan pemuda tampan selama dua tahun, dia merasa frustasi. Sebab, harapan miliknya hancur. Hal tersebut diketahui dari perkataan tokoh Seniman sebagai berikut.

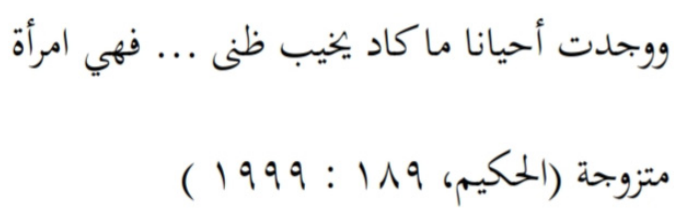

Artinya:

Dan terkadang aku mendapatkan sesuatu yang membuatku frustasi. Perempuan itu telah menikah (AlChakīm, 1999, h.189).

Kutipan tersebut menggambarkan bahwa tokoh Seniman merasakan frustasi. Rasa frustasi atau kecewa yang dialami oleh Seniman disebabkan dia mengetahui gadis muda yang dicintainya telah menikah. Perasaan frustasi atau kecewa yang dirasakan oleh tokoh Seniman merupakan bagian dari kriteria penilaian yang tidak menyenangkan.

Kedua, penilaian menyenangkan dan tidak menyenangkan tersebut bereaksi secara rasional. Hal tersebut seperti yang telah dijelaskan sebelumnya bahwa pikiran dan perasaan adalah fungsi rasional. Oleh karena itu, kedua hal itu melibatkan suatu keharusan untuk memutuskan sesuatu, yakni apakah dua ide tersebut saling berhubungan atau tidak (berfikir) dan menyenangkan atau tidak (perasaan), (Jung dalam Alwisol, 2009, h.46).

Pada dasarnya, setiap individu mempunyai keempat fungsi seperti yang telah dijelaskan tersebut, yakni pikiran, perasaan, penginderaan dan intuisi. Akan tetapi, hal itu biasanya hanya ada satu sifat yang dominan atau superior dalam setiap individu. Dalan cerpen Wajh Al-Haqiqāh karya Taufĩ AlChakīm ini, tokoh Seniman merupakan orang yang bertipe perasa.

Sikap jiwa adalah arah energi psikis umum dalam bentuk orientasi manusia teradap dunianya. Arah energi psikis tersebut sebanding dengan arah orientasi manusia terhadap dunia, yaitu ke luar atau ke dalam (Suryabrata, 2007, h.161). Jung (dalam Alwisol, 2009, h.45-46) membagi sikap jiwa menjadi dua, yaitu introvers dan ekstravers. Sikap introvers mengarahkan kepribadian kepada pengalaman subjektif, memusatkan diri kepada dunia dalam dan cenderung bersifat privasi, suka menyendiri, dan pendiam. Pada umumnya, orang yang bersikap introvers sibuk dengan kehidupan internal mereka sendiri. Sikap ekstravers mengarahkan kepribadian kepada pengalaman objektif. Hal ini 
memusatkan perhatiannya ke dunia luar, suka berinteraksi dengan orangorang yang berada di sekitarnya, peduli, aktif, dan ramah. Orang yang mempunyai sikap ekstravers sangat menaruh perhatian terhadap dunia luar dan dunia di sekitarnya, aktif, santai, dan tertarik kepada dunia luar.

Berdasarkan uraian tersebut, tokoh Seniman merupakan tokoh yang mempunyai kepribadian ekstravers. Individu dengan kepribadian ekstravers cenderung mengarahkan kepribadian kepada pengalaman objektif dan memusatkan perhatiannya kepada dunia luar, seperti suka berinteraksi, peduli, aktif dan ramah. Hal tersebut dapat dilihat dari sikap seniman ketika mengetahui semua cerita dan masalah yang menimpa si gadis muda, seperti ungkapkan di bawah ini.

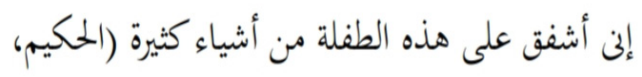

$$
(1999: 19 \varepsilon
$$

\section{Artinya:}

Pada dasarnya aku hanya merasa kasihan terhadap berbagai permasalahan yang dialami oleh gadis muda ini (Al-Chakīm, 1999, h.194).

Berdasarkan kutipan tersebut dapat dipahami bahwasannya tokoh Seniman merasa kasihan terhadap si gadis muda dengan berbagai permasalahan yang dihadapi. Hal tersebut menunjukkan bahwa tokoh Seniman mempunyai sikap peduli terhadap orang lain. Oleh karena itu, tokoh Seniman merupakan orang yang bertipe ekstravers, yaitu menaruh perhatian terhadap dunia luar dan lingkungan sekitarnya. Dia adalah pribadi yang terbuka. Hal ini ditunjukkan dengan rasa belas kasihan tokoh Seniman kepada gadis muda.

Sikap tokoh Seniman yang terbuka ini membuat dirinya mudah menyesuaikan diri dengan lingkungan sekitarnya. Oleh karena itu, orang yang bertipe ekstravers cenderung aktif, santai, ramah, dan tertarik pada dunia luar. Seniman senantiasa memperhatikan dunia luar dan lingkungan sekitarnya. Hal itu dapat diketahui dari peristiwa dalam kutipan berikut.

$$
\begin{aligned}
& \text { لقد فكرت كيف أيتطيع أن أذهب هذه الصغيرة من } \\
& \text { حيث لا تدرى (الحكيم، \&19 } 1999 \text { (199) }
\end{aligned}
$$

Artinya:

Aku telah berpikir bagaimana agar aku dapat mengajarkannya kepada hal-hal yang berharga tanpa diketahuinya (Al-Chakīm, 1999, h.194).

Kutipan tersebut menunjukkan sikap kepedulian tokoh seniman terhadap si gadis muda. Seniman ingin membantu gadis muda tersebut menjadi seorang gadis yang lebih berharga dan bernilai. Oleh karena itu, tokoh Seniman ingin mengajarkan hal-hal yang dapat membuat si gadis menjadi seseorang yang lebih berharga tanpa diketahui oleh gadis muda tersebut. Sikap kepedulian tokoh Seniman terhadap si gadis muda merupakan tipe sikap ekstravers.

Sikap dari kepribadian ekstravers dan introvers ini mempunyai hubungan yang kompensatoris (Suryabrata, 2007, h.162). Maksudnya, hal ini menunjukkan gejala introvers dan ekstravers saling 

dan Gadis Muda dalam Cerpen "Wajh Al Haqiqāh"

mengimbangi. Berdasarkan uraian tersebut dapat disimpulkan bahwa fungsi jiwa tokoh Seniman adalah tokoh yang bertipe perasa dan sikap jiwanya adalah ekstravers.

\section{Kepribadian Tokoh Gadis Muda dalam Cerita Pendek Wajh Al- Haqiqāh}

Kepribadian gadis muda terbentuk secara sadar. Karakter tokoh gadis muda terbentuk karena lingkungan yang ada di sekitarnya. Sebab, lingkungan memberikan pengaruh yang sangat besar terhadap kepribadian seseorang. Hal ini dapat dilihat dari karakter gadis muda yang dalam kesehariannya. Dia merupakan seorang gadis yang pemalas dan tidak mempunyai kegiatan yang pasti. Hal tersebut dapat diketahui dari ungkapan atau pandangan Seniman terhadap Gadis Muda tersebut. Sebagai buktinya, berikut ini adalah kutipan tersebut.

$$
\begin{aligned}
& \text { و هي مثال للكسل و التراخى و الفراغ, لا تستيقظ } \\
& \text { في الصباح إلا قليل الظهر، و لا تنام إلا في الثانية بعد منت } \\
& \text { الليل، غوض متأخر . و وقت ينفق في الزينة و مشاغل نس } \\
& \text { تافهة (الحكيم، 1119 : 1999) }
\end{aligned}
$$

Artinya:

Sedangkan sang istri adalah gadis pemalas, lamban dan tidak memiliki kegiatan pasti. Dia tidak akan bangun di pagi hari kecuali waktu dhuhur lewat, dan dia tidak akan tidur sebelum jam dua lewat tengah malam. Dia akan bangun telat. Setelah itu, dia akan sibuk dengan berdandan dan melakukan kegiatan-kegiatan perempuan yang tidak penting (Al-Chakīm, 1999, h.189).

Berdasarkan kutipan tersebut dapat dipahami bahwasannya tokoh Gadis Muda tersebut merupakan seorang pemalas dan tidak mempunyai kegiatan yang bermanfaat. Dia tidak pernah bangun di pagi hari sebelum waktu dhuhur tiba dan tidak akan tidur sebelum tengah malam. Dia selalu bangun telat. Kemudian setelah dia bangun, dia hanya melakukan hal-hal yang tidak penting, seperti sibuk dengan berdandan dan melakukan kegiatankegiatan yang tidak penting lainnya. Hal tersebut dipengaruhi oleh lingkungan sekitar losmen yang dia tempati. Dia hanya sendirian di losmen dan tidak mempunyai saudara ataupun teman. Oleh karena itu, dia hanya menyibukkan diri dengan urusan pribadinya yang tidak penting tersebut.

Kepribadian tokoh Gadis Muda tersebut dianggap sebagai orang yang bertipe perasa, yaitu memberi pengalaman subjektif manusia berupa sifat malas (Jung dalam Alwisol, 2009, h.46). Sifat malas merupakan sebuah sikap tidak senang melakukan sesuatu. Selain itu, kepribadian tokoh Gadis Muda berdasarkan pada fungsi jiwa bertipe perasa juga dapat dilihat dari peristiwa berikut.

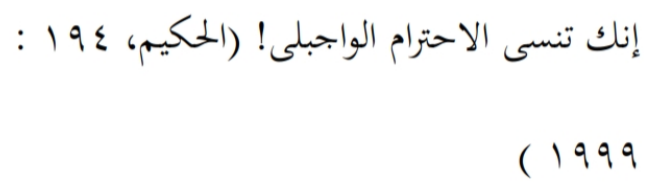

Artinya:

Apakah kamu sudah lupa etika kesopananmu terhadapku! (AlChakìm, 1999: 194). 
Berdasarkan kutipan tersebut dijelaskan bahwa tokoh Gadis Muda sedang dalam keadaan penuh kemarahan. Tokoh Gadis Muda tersebut marah kepada salah satu teman lakilaki suaminya ketika teman suaminya tersebut menyodorkan sejumlah uang kepada gadis muda tersebut. Sebab, laki-laki itu mengira tokoh Gadis Muda tersebut sedang membutuhkan seorang pria untuk menemaninya. Kepribadian Gadis Muda tersebut merupakan orang yang bertipe perasa yaitu sifat marah.

Tokoh Gadis Muda memiliki kepribadian introvers. Kepribadian introvers ini merupakan kepribadian yang tertutup. Individu dengan tipe introvers dipengaruhi oleh dunia subjektif yaitu dunia di dalam individu itu sendiri (Suryabrata, 2007, h.162). Individu dengan kepribadian introvers cenderung sukar bergaul, tertutup jiwanya dan sulit untuk berkomunikasi dengan orang lain. Ciri-ciri tersebut sesuai dengan tokoh gadis muda. Hal itu dapat dilihat dari peristiwa yang dialami oleh gadis muda, sebagaimana dalam kutipan berikut ini.

$$
\begin{aligned}
& \text { و هي مثال للكسل و التراخى و الفراغ، لا تستيقظ في صباح، } \\
& \text { هو متأخر، و وقت ينفق في الزينةو مشاغل نسوية تافهة ثم غداء } \\
& \text { تتناوله بمفردها (الحكيم، } 1199 \text { : 1999) }
\end{aligned}
$$

Artinya:

Gadis Muda adalah gadis pemalas, lamban dan tidak memiliki kegiatan pasti, dia tidak akan bangun di pagi hari, dia akan bangun telat, setelah itu dia akan sibuk berdandan dan melakukan kegiatan-kegiatan perempuan yang tidak penting, kemudian dia akan makan sendiri (Al-Chakīm, 1999: 189).
Kutipan tersebut menjelaskan bahwa tokoh Gadis Muda merupakan gadis yang pemalas, lamban, dan tidak mempunyai kegiatan pasti. Dia tidak pernah bangun di pagi hari, melainkan dia selalu bangun telat. Setelah terbangun, dia hanya melakukan hal-hal yang tidak penting, seperti berdandan. Setelah berdandan, dia hanya makan siang sendirian. Hal itu menunjukkan bahwa gadis muda tersebut adalah orang yang mempunyai kepribadian introvers. Tipe-tipe kepribadian introvers ditunjukkan dengan kebiasaan tokoh Gadis Muda yang selalu melakukan halhal yang tidak pasti dan tidak berguna. Selain itu, dia juga suka menyendiri di dalam kamar tanpa ada seorang teman. Dengan demikian, tokoh Gadis Muda tersebut kurang menjalin komunikasi dan interaksi dengan lingkungan sekitarnya.

Sikap Gadis Muda yang tertutup membuat dirinya sulit untuk bergaul dan berinteraksi dengan orang lain. Hal itu dapat dilihat dari sikap tokoh Gadis Muda terhadap tokoh Seniman sebagai berikut.

$$
\begin{aligned}
& \text { و لم أستطيع أن أحادثها أكثر من ذلك، فقد مملت } \\
& \text { آنيتها و حيت برأسها تحتة حفيفة، كلها تحفظ و انصرفت إلى } \\
& \text { حجرقا. و تر كتنى فن مكاني كالتمثال (الحكيم، } 191 \text { : } \\
& (1999
\end{aligned}
$$

Artinya:

Sayangnya aku tidak dapat berbicara lebih banyak dengan dirinya. Dia telah mengambil vas bunganya. Dengan sedikit menganggukan kepalanya, diapun melenggang pergi menuju kamarnya. Ia meninggalkan aku begitu saja yang berdiri seperti patung (Al-Chakīm, 1999, h.198). 
Berdasarkan kutipan tersebut dijelaskan bahwa tokoh Seniman sedang berbicara dengan tokoh Gadis Muda. Akan tetapi, mereka tidak dapat berbicara lebih banyak dikarenakan tokoh Gadis Muda pergi begitu saja dan meninggalkan Seniman dengan membawa vas bunganya. Hal itu menunjukkan sikap Gadis Muda yang begitu tidak mempedulikan orang lain. Dengan demikian, tokoh Gadis Muda tersebut merupakan seseorang yang bertipe introvers. Dia adalah seseorang dengan kepribadian tertutup. Orang yang bertipe introvers dalam beradaptasi dengan dunia luar kurang baik, jiwanya tertutup, sukar bergaul, sukar berhubungan dengan orang lain, dan kurang dapat menarik hati orang lain (Suryabrata, 2007, h.162). Berdasarkan uraian tersebut, jiwa tokoh Gadis Muda memiliki tipe perasa dan sikap jiwanya adalah introvers.

\section{SIMPULAN}

Tokoh dalam cerpen Wajh AlHaqiqāh karya Taufīq Al-Chakīm memiliki bermacam kepribadian yang terlihat dari masing-masing tokoh. Fungsi jiwa tokoh Seniman merupakah tokoh yang bertipe perasa dan sikap jiwanya adalah ekstravers. Fungsi jiwa tokoh Gadis Muda adalah tipe perasa dan sikap jiwanya adalah introvers. Kepribadian tokoh cerita dalam cerita ini merupakan sebuah penerapan teori pisologi sastra dengan konsep struktural. Artinya, kepribadian para tokoh tersebut dapat dikatakan sebagai bagian dari simbol atau cara menyembunyikan ketidaksadaran dari pengarangnya sendiri.

Kajian terhadap struktur kepribadian dengan mendasarkan pada simbol satu atau dua tokoh dalam cerita memang tidak dapat mengungkapkan kesadaran dari pengarang secara keseluruhan. Hal ini sekaligus menandakan bahwa kepribadian para tokoh dalam cerita pendek ini merupakan kepribadian "yang semu". Artinya, kepribadian tokoh atau karakterisasi tokoh cerita ini bertujuan mendukung struktur naratif cerita. Karakterisasi tokoh cerita menjadi bagian yang penting dalam cerita sebab dia juga berfungsi mengerakkan alur cerita atau tata naratif cerita.

\section{DAFTAR PUSTAKA}

Al-Chakīm, T. (2008). "Arinillāh" dalam Anif Sirsaeba. Dalam Perjamuan Cinta. Jakarta: Penerbit Republika

Al-Chakīm, T. (1999). Arinillāh. Mesir: Dar Misr Li thaba'ah.

Al-Chakīm, T. (2014). Arinillāh. (penerjemah: Yessi Basyaruddin). Jakarta: Maktabah Usrah.

Alwisol. (2009). Psikologi Kepribadian (Edisi Revisi). Malang: UMM Press.

Farkhati. (2014). "Aspek Kepribadian \& Profil Tokoh Utama dalam Kumpulan Cerpen Arinillāh Karya Taufiq Al-Chakīm (Analisis Psikologi Sastra Sigmund Freud)". Skripsi, Fakultas Ilmu Budaya, Universitas Sebelas Maret, Surakarta. 
Khoidah, N. (2017). "Kepribadian Tokoh Protagonis dan Antagonis dalam Asy'ab Fi Biladil Waq Waq (2002) dan Asy'ab Fi Michnah (2002) Karya Wajh Yaqub AsSayyid Kajian Psikologi Sastra" Skripsi, Fakultas Ilmu Budaya, Universitas Sebelas Maret, Surakarta.

Kumala. (2014). "Al-Qishah Al-Qoshiroh Imroah GholabatSyaitan Li Taufiq Al-Chakīm (Dirasah Tahliyan Sikulujiya Lil Victor Franki)". Skripsi, Universitas Islam Sunan Kalijaga, Yogyakarta.

Kurniawan, H dan Sutardi. (2012). Penulisan Sastra Kreatif. Yogyakarta: Graha Ilmu.

Sehadi, Y. (2014). Mengenal 25 Teori Sastra. Yogyakarta: Penerbit Ombak.

Suryabrata, S. (2007). Psikologi Kepribadian. Jakarta: PT RajaGrafindo Persada.

Teeuw, A. (1984). Sastra dan Ilmu Sastra: Pengantar Teori Sastra. Jakarta: Pustaka Jaya.

Wellek, R dan Warren. A. (2013). Teori Kesusastraan. Jakarta: PT Gramedia Pustaka Utama.

Wulandari, F. (2017). "Relasi Anak dan Lingkungan Sekitarnya dalam Teks Akhi Ash-Shaghir Yamsyi (2002) Karya Hasan Abbdullah Kajian Psikologi Sastra". Skripsi, Fakultas Ilmu Budaya, Universitas Sebelas Maret, Surakarta 